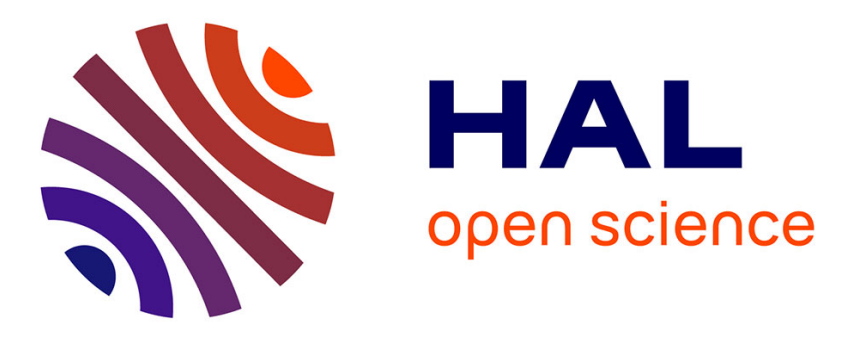

\title{
Topsoil disturbance reshapes diaspore interactions with ground-foraging animals in a megadiverse grassland
}

André Jardim Arruda, Fernanda V. Costa, Tadeu J. Guerra, Patrícia A. Junqueira, Roberta L. C. Dayrell, Messeder V. S. João, Rodrigues T. S. Anna, Elise Buisson, Fernando Augusto Oliveira Silveira

\section{To cite this version:}

André Jardim Arruda, Fernanda V. Costa, Tadeu J. Guerra, Patrícia A. Junqueira, Roberta L. C. Dayrell, et al.. Topsoil disturbance reshapes diaspore interactions with ground-foraging animals in a megadiverse grassland. Journal of Vegetation Science, 2020, 31 (6), pp.1039-1052. 10.1111/jvs.12866 . hal-02982018

\section{HAL Id: hal-02982018 https://hal.science/hal-02982018}

Submitted on 28 Oct 2020

HAL is a multi-disciplinary open access archive for the deposit and dissemination of scientific research documents, whether they are published or not. The documents may come from teaching and research institutions in France or abroad, or from public or private research centers.
L'archive ouverte pluridisciplinaire HAL, est destinée au dépôt et à la diffusion de documents scientifiques de niveau recherche, publiés ou non, émanant des établissements d'enseignement et de recherche français ou étrangers, des laboratoires publics ou privés. 
1 Running title: Disturbance reshapes diaspore interactions

3

4

5

6

7

8

9

10

11

12

13

14

15

16

17

\section{Topsoil disturbance reshapes diaspore interactions with ground-foraging animals in a megadiverse grassland}

Andre J. Arruda ${ }^{1,2,3 *}$, Fernanda V. Costa ${ }^{4}$, Tadeu J. Guerra ${ }^{2}$, Patrícia A. Junqueira ${ }^{2}$, Roberta L.C. Dayrel1 ${ }^{1,2}$, João V. S. Messeder ${ }^{2}$, Hanna T. S. Rodrigues², Elise Buisson², Fernando A. O. Silveira ${ }^{2,5}$

1 University of Western Australia, School of Biological Sciences, Australia

2 Federal University of Minas Gerais, Department of Botany, Brazil

3 Avignon Université, Institut Méditerranéen de Biodiversité et d'Ecologie, CNRS, IRD, Aix Marseille Université, IUT d'Avignon, AGROPARC, France

4 Federal University of Ouro Preto, Graduate School in Ecology of Tropical Biomes, Brazil

5 Federal University of Minas Gerais, Department of Genetics, Ecology and Evolution, Brazil

*Corresponding author: ajarruda@gmail.com 


\section{Abstract \\ Questions}

Anthropogenic disturbances are known to be followed by extremely poor recovery in edaphic grasslands. However, the role of interactions with diaspore predators and secondary dispersers, which compose the dispersal filter and modulate plant community recovery, remains overlooked. We performed field experiments to investigate how soil disturbances affect diaspore interactions with the ground-foraging fauna to better understand how disturbance influences regeneration potential.

\section{Location}

Campo rupestre vegetation, megadiverse edaphic grasslands, southeastern Brazil.

\section{Methods}

We used diaspores from five native species to compare removal rates between disturbed (topsoil removal) and preserved sites. We controlled invertebrate and vertebrate access to determine their role. Additionally, we assessed differences in the diaspore removal effectiveness (DRE) and the structure of animal-diaspore interactions through network based-approach.

Results

For three species, diaspore removal was relatively high (between 50 and 100\%). Invertebrates were the most common removal agents in both disturbed and preserved sites. Interactions with foraging fauna and removal rates were $20 \%$ smaller in disturbed sites. Considering all diaspores removal events in disturbed sites, $24 \%$ resulted in the displacement from disturbed to preserved sites, but no diaspore was transported from preserved to disturbed ones. The animal-diaspore network was exclusively composed by ant-diaspore interactions and were more diverse and robust in preserved sites compared to disturbed ones. Seed predator ants (Pheidole and Dorymyrmex) were more common in disturbed sites. Furthermore, we found significant differences in the DRE between ant species and site types, suggesting specificity in the provision of dispersal services.

\section{Conclusions}

Topsoil removal affected removal proportions, DRE and ant-diaspore interaction network structure. The lack of diaspore dispersal towards disturbed sites indicates that soil removal affects secondary seed removal dynamics, precluding recovery potential. Disturbance negatively affected diaspore fate by reshaping interactions with ground-foraging secondary seed dispersers and predators, constraining the development of seed bank and thus vegetation dynamics and resilience. 
Keywords: ants, campo rupestre, degradation, diaspore removal, myrmecochory, natural recovery, seed limitation, seed predation

\section{Introduction}

Ground-foraging animals may affect seed fate by interacting with diaspores handled or dispersed by primary dispersers (Roberts \& Heithaus 1986; Chambers \& MacMahon 1994; Vander Wall et al. 2005). Empirical studies examining secondary diaspore-animal interactions have shown a strong variability among plant species and habitat types (Schupp \& Fuentes 1995; Chapman \& Chapman 1996, Lambert 2002; Roselli 2014), and have been crucial to the development of theoretical models regarding seed fate (Janzen 1970, Hammond \& Brown 1998; Martinson \& Fagan 2014; Török et al. 2018). By moving seeds, ground-foraging animals may expand seed shadows generated by primary dispersers (Christianini \& Oliveira 2009), provide additional opportunity for seeds to escape predation or fire (Giladi 2006; Rico-Gray \& Oliveira 2007; Rico-Gray \& Oliveira 2007), and in some cases lead to direct seed deposition into nutrient-rich soils (Sternberg et al. 2007, Arnan et al. 2012). On the other hand, seed removal can result in seed loss by predation or deposition in unfavorable sites, affecting plant community assembly and recovery in disturbed areas (Calviño-Cancela 2007; Denham 2008). Diaspore-animal interactions in tropical ecosystems often involve different agents of dispersal in subsequent steps (Vander Wall \& Longland, 2004; Camargo et al. 2019). Secondary seed dispersal has been commonly attributed to vertebrates, such as rodents (Feer \& Forget 2002; Lessa et al. 2013; Genrich et al. 2017). However, the contribution of invertebrates as secondary diaspore dispersers still remains poorly understood (Magalhães et al. 2018; Camargo et al. 2019). Ants are well-known as seed predators (Retana et al. 2004; Costa et al. 2017), but they can also play an important role as seed dispersers in Neotropical savannas (Christianini \& Oliveira 2009, 2010), often improving seed survival and germination by feeding upon fruit pulp 
and cleaning seeds, which become less vulnerable to pathogen attack (Passos \& Oliveira 2003; Christianini et al. 2007). Even though most diaspores in Neotropical savannas do not present any apparent characteristics that promote ant dispersal (Christianini \& Oliveira 2010), evidences suggest ants as important seed dispersers of non-myrmecochorous plant species (e.g., Leal \& Oliveira 1998; Christianini et al. 2007; Christianini \& Oliveira 2009, 2010; Lima et al. 2013; Guerra et al. 2018).

The Brazilian campo rupestre, an Old Climatically-Buffered Infertile Landscape (OCBIL sensu Hopper et al. 2016), encompasses old-growth fire-prone tropical grasslands, associated to extremely poor soils on ancient mountaintops that harbors a highly diversified flora with remarkable levels of plant endemism (Echternacht et. al. 2011; Silveira et al. 2016; Colli-Silva et al. 2019). Nevertheless, along the past decades, the vegetation dynamics in these unique landscapes has been hampered by anthropogenic disturbances, especially topsoil removal associated with quarrying and mining activities (Silveira et al. 2016; Fernandes et al. 2018). Plant and ant communities from campo rupestre, although highly resilient to endogenous disturbances, such as fires (Fagundes et al. 2015; Neves et al. 2016; Le Stradic et al. 2018a), are extremely vulnerable to human-induced exogenous soil disturbances (Le Stradic et al. 2018b; Buisson et al. 2019), which can be partially explained by dispersal limitation (Morellato \& Silveira 2018).

In old-growth grasslands, plant species disperse poorly and at low rates, making community re-assembly a lengthy process (Bond \& Parr 2010; Parr et al. 2014; Veldman et al. 2015; Buisson et al. 2019). In seed-limited ecosystems, such as campo rupestre, reductions in seed quantity (e.g., seed predation) may compromise recruitment, while processes that increase seed dispersal success may prompt it (Calviño-Cancela 2007). Nevertheless, only a handful of studies have addressed the influence of diaspore-animal interactions on vegetation dynamics in 
campo rupestre (Lima et al. 2013; Guerra \& Pizo 2014, Guerra et al. 2016, 2017, 2018), and none have addressed this topic within a disturbance context.

Here, we aimed to ascertain how topsoil disturbance affects diaspore interaction with ground-foraging fauna in campo rupestre. First, we compared the proportion of diaspores removed for five plant species between disturbed and preserved sites using control and vertebrate-exclosure treatments (to differentiate the role of vertebrates and invertebrates in diaspore removal). Then, we qualitatively compared diurnal animal-diaspore interactions between disturbed and preserved sites for diaspores of three plant species that had significant removal rates in the first experiment. As ants were the only group observed in this second experiment, we recorded ant-diaspore interactions and explored their possible outcomes through multilayer networks. Finally, we explored the effects of topsoil disturbances on interaction structure and seed dispersal effectiveness among ant species in both disturbed and preserved sites.

\section{Material and methods}

\section{Study area}

We conducted this study at the vicinity of the Serra do Cipó National Park, in the southern portion of the Espinhaço Range, southeastern Brazil ( $\left.43^{\circ} 35^{\prime} \mathrm{W}, 19^{\circ} 17^{\prime} \mathrm{S}\right)$. The annual precipitation at the study site averages around $1,400 \mathrm{~mm}$ and the climate is markedly seasonal with most rainfall concentrated between October and March (Brito et al. 2017). Altitude at the study site ranges between 1,150 and $1,300 \mathrm{~m}$ a.s.l. The main vegetation at the study site is campo rupestre, an old-growth, fire-prone grassland established on quartzite-derived rocks, with shallow and severely nutrient-impoverished sandy soils in mountaintops (Veldman et al. 2015; Silveira et al. 2016, Mucina 2018). The landscape encompasses a mosaic formed by 
patches of rocky outcrops and boulders where sclerophyllous treelets and shrubs grow and patches of an herbaceous stratum, dominated by monocots and sparsely distributed shrubs (Le Stradic et al. 2015; Guerra et al. 2017).

During the paving of the MG-010 highway in 2002, small quarries were exploited for soil extraction, destroying vegetation and virtually removing all topsoil horizons. Owing to disturbance, the community composition between preserved and disturbed sites remains drastically different even 15 years after the disturbance (Le Stradic et al. 2018b). For the present study, we selected four disturbed sites of at least $100 \mathrm{~m}^{2}$ and a preserved (control) site nearby each disturbed one. In all sites, the paired disturbed and preserved sites were adjacent at approximately 30 meters away from each other and each pair distant at least $2 \mathrm{~km}$ from another. The preserved sites are grasslands used as the reference ecosystem of the disturbed sites. The disturbed sites have extensive areas of bare ground and a few grassland species. All permits to visit and collect biological data were authorized by the Instituto Chico Mendes de Conservação da Biodiversidade (ICMBio) of the Brazilian Ministry of Environment. Data collection in sites located on private lands was authorized by the owners and ICMBio.

\section{Diaspores from native species}

We used diaspores from five native plant species commonly found in the study area, which have similar likelihood of being dispersed to disturbed and adjacent preserved sites, to compare diaspore removal and interactions with foraging animals between diaspore types and site types (Appendix S1). We selected the species based on four criteria: (1) diaspore size; not too small to prevent the diaspores from being blown away, (2) presence of fleshy parts or rich endosperm to potentially attract both vertebrates and invertebrates, (3) diaspore availability; to allow setting replicates for the removal experiments (between 600 to 1000 diaspores per species), and (4) phylogenetic and morphological diversity. In our experiment, we used seeds 
of Stryphnodendron gracile (Fabaceae) and Davilla elliptica (Dilleniaceae). Additionally, we used berries of three species: Miconia irwinii (Melastomataceae), Byrsonima vacciniifolia (Malpighiaceae) and Coccoloba cereifera (Polygonaceae), all primarily dispersed by birds (see Guerra et al. 2016).

Stryphnodendron gracile (Fabaceae) is a Brazilian endemic small shrub, found exclusively in the cerrado biome (Occhioni 1990). It typically produces seeds characterized by a very rigid seed coat (De Lima 1985). Davilla elliptica (Dilleniaceae) is a widespread species in the cerrado biome (Fraga 2012) and produces fruits containing up to two seeds surrounded by an aril (Pott \& Pott 1994). Miconia irwinii (Melastomataceae) is a Brazilian endemic treelet found exclusively in rocky outcrops at campo rupestre, with single plants producing up to 4,000 water- and sugar-rich purplish-black berries that are primarily dispersed by birds (Guerra et al. 2017), and secondarily dispersed by ants and lizards, but being also predated by ground dwelling ants and rodents (Guerra et al. 2018). Byrsonima vacciniifolia (Malpighiaceae) is a Brazilian endemic treelet found exclusively in the cerrado and caatinga biomes (Mamede \& Francener 2015), which typically produces water- and sugar-rich yellow fruits with a striking aroma (Leal et al. 2007). Coccoloba cereifera (Polygonaceae) is a narrowly distributed endemic species from campo rupestre sandy grasslands in southeastern Brazil (Ribeiro \& Fernandes 1999), which typically produces fleshy violet fruits. We collected all native diaspores during the fruiting period of each species and set them in the refrigerator $\left(4^{\circ} \mathrm{C}\right)$ until the commencement of each experiment.

\section{Removal experiment design}

Experiment A. We performed randomized block factorial experiments to compare diaspore removal rates between disturbed and preserved sites, and between vertebrate-exclosure and control treatments. In each sampling station, we used either wire frames to create a 
treatment accessible to invertebrates and vertebrates (control treatment) or wired cages to create treatments to exclude vertebrates, but accessible to invertebrates (vertebrate-exclosure treatment; Appendix S2). We constructed the wire cages $(17 \times 17 \times 8 \mathrm{~cm})$ fenced with wire mesh $(1.2 \mathrm{~cm})$. The wire frames were constructed without mesh (i.e., access to both vertebrates and invertebrates) and were used to control possible effects of wire presence on diaspore removal (Guerra et al. 2018). We performed five experiments separately, one for each species, simultaneously in all sites for each species. We paired our removal stations in six blocks distributed along four disturbed and four preserved adjacent sites. In each block, we thus set paired control (wire frame) and vertebrate-exclosure (wire cage) treatments, totaling 96 samples per plant species (experimental design shown in Appendix S2). Blocks were distant nearly $1 \mathrm{~m}$ from each other.

We conducted the experiment in the summer from December 2016 to March 2017, the period of higher activity by ground-foraging animals (Costa et al. 2018; Pol et al. 2011). The sampling effort for each species occurred during the same week within this 3-month interval. Each sampling station consisted of diaspore piles placed in the ground over a filter paper, always controlling for the number of diaspores for each species. No rain or strong winds occurred during the observation periods, reducing the possibility that seeds were lost due to abiotic factors. Using the filter paper was important to gather and count diaspore during experiments. We used white filter papers considering this the less contrasting color with the white sandy soil in the study sites. Any possible contrast effects by the filter paper leading to attraction or deterrence of animals is present in all treatments.

We placed 10 diaspores per sampling station totaling 960 diaspores per species, with the exception of Byrsonima and Davilla, in which we placed eight and six diaspores per sampling station, totaling 768 and 576 diaspores, respectively. We evaluated the proportion of diaspores removed in all treatments by exhaustively searching for diaspores in stations after 
48h of exposure in the field (Guerra et al. 2018). The proportion of diaspores removed (PDR) from each sampling station was calculated as:

$$
P D R=(N r c \text { or Nre }) / N o
$$

where No is the number of offered diaspores, and Nrc and Nre are the number of recovered diaspores in the control treatment and in the vertebrate-exclosure treatment, respectively.

Experiment B. To determine the identity of animal species interacting with diaspores, the frequency of interactions, and their behavior towards the diaspores, we performed direct diurnal observations on diaspore piles in disturbed and preserved sites. To do that, we used diaspore of the three species that presented the most significant removal rates in the first experiment: Byrsonima vacciniifolia, Davilla elliptica and Miconia irwinii.

For these species, we performed direct observations bouts totaling 20 hours for each species, equally distributed between the four disturbed and preserved sites. We obtained and handled the diaspores as described above, placing five diaspores of each species directly on the ground over a filter paper, without any structure around. We performed the observation bouts during the daytime, always between 10:00 AM and 05:00 PM. Each bout comprised 50 minutes of continuous observation performed by a single observer. We followed the animals that effectively removed diaspores from piles, recorded dispersal distances, the final destination (e.g., ant nest and preserved or degraded site), and animal behavior towards the diaspore whenever possible. Ants were the only group of animals observed interacting with diaspores. Interacting ant specimens were collected, preserved in $70 \%$ alcohol, and identified to the lowest possible taxonomic level using the taxonomic key provided by Baccaro et al. (2015). Collected specimens were also compared to a reference collection from the Insect Ecology Lab at UFMG (Costa et al. 2016), in order to ensure species identification. Ant behavior towards diaspores was classified as follows: (1) removal, when displacing the diaspore further than $5 \mathrm{~cm}$; (2) 
depulping, when consuming or removing diaspore pulp, with no diaspore removal $(<5 \mathrm{~cm})$; $(3)$ interaction, when manipulating diaspore, without depulping or removing the diaspore $(<5 \mathrm{~cm})$ (Lima et al. 2013, Costa et al. 2016). We did not considered inspection as an interaction, when ants quickly touched and left the diaspore.

\section{Statistical analyses}

We employed generalized linear mixed effects models (GLMMs, glmer function for non-normal datasets, with lme4 package in $\mathrm{R}$ ) with fixed and random effects to analyze the datasets of diaspore removal experiments (Bolker 2015). In each model, site type (disturbed vs. preserved), treatment (vertebrate-exclosure $v s$. control) and possible interactions among these factors were considered as predictive variables of fixed effects. Sampling blocks were nested within sites and grouped as random effects to account for the spatial heterogeneity of samples (Bates et al. 2014). The response variables were the proportions of diaspore removed after $48 \mathrm{~h}$ of exposure in the field, separately for each species. We performed analyses assuming a binomial distribution error of response variable. Regarding the interactions between variables, when significant, we run post-hoc contrast tests (Crawley 2013).

To evaluate network structure in disturbed and preserved sites, considering both quantitative and qualitative components of all interaction events which occurred between animals and diaspores piles, we used two network metrics: interactions' Shannon diversity per site $\left(\mathrm{H}_{2}\right.$ - see Bersier et al. 2002; Blüthgen et al. 2008) and robustness with regard to cumulative random extinctions of ant species (Memmot et al. 2004; Burgos et al. 2007). In our local networks (i.e., site level), consistent with other studies on ant-plant interactions (e.g., Costa et al. 2018), each interaction frequency was computed based on the interaction between an animal species with an individual diaspore, not the number of workers recruited per diaspore species. Hence, in each site we included all records from all interaction types that occurred between ants 
and diaspores piles of each of the three species, to build weighted matrices with diaspore species as rows and ant species as columns, filling cells with the number of events observed between one diaspore species $i$ and one ant species $j$. Network metrics (i.e. Shannon interaction diversity and robustness) were calculated for each interaction matrix. In total, we had eight matrices/networks corresponding to each site ( $n=4$ per site type). Network metrics were calculated using the R package bipartite (Dormann et al. 2008). Thus, each metric value was fitted as response variable, and site type as predictive variable in generalized linear models (GLMs; Crawley 2013). Furthermore, we built a multilayer network comprising all types of events recorded between ants and diaspore species, in order to assess how disturbance might prompt distinct patterns of interaction outcomes. Hence, each network layer corresponded to a distinct type of ant-diaspore association, i.e., removal, depulping and interaction (see Costa et al., 2016 for a similar approach).

To access possible differences in seed dispersal effectiveness (SDE) between ant species present in disturbed and preserved sites, we constructed interaction effectiveness landscapes adapted from Schupp et al. (2010, 2017). We combined two variables into an index of 'diaspore removal effectiveness' (DRE) for each ant species from disturbed and preserved sites using the formula:

\section{Eqn 2: DRE $=$ QTC $\times$ QLC.}

The quantitative component (QTC) corresponded to the frequency of interactions between each ant species and all available diaspores in each site type. The qualitative component (QLC) corresponded to the frequency of diaspore removed by each ant species for all observation bouts in each site type. For each ant species, we computed a measure of total dispersal service that integrates the quality and quantity components of service offered (effectiveness package in R). We considered highly-effective dispersers those species that had high values of DRE (high quantitative and qualitative values); inefficient dispersers as those 
species that had low DRE values (low quantitative and qualitative values); and lowly-effective dispersers as those species that had intermediate DRE values (low quantitative values and high qualitative values or high quantitative values and low qualitative values). We performed all statistical analyses in R (R Core Team 2017) and networks graph using Pajek 4.09 (Batagelj \& Mrvar 1998).

\section{Results}

Experiment A. Diaspore removal experiment

We found a large variation on diaspore removal among plant species, according to treatments and site types (Table 1). Removal of Coccoloba and Stryphnodendron diaspores was negligible, smaller than $0.1 \%$ across all sites and treatments (Table 1), and thus we excluded these two species from further analyses and will only refer to the other three species from now on. Average diaspore removal rates were $32 \%$ for Byrsonima, $67 \%$ for Davilla and, $52 \%$ of Miconia. However, we found a large range of variation within species (Table 1).

We observed higher percentages of diaspore removal in preserved sites compared to disturbed sites for all species (Table 1, Fig. 1). Diaspore removal in the control treatment of all species were $6 \%$ to $16 \%$ higher than in the vertebrate-exclosure treatment, with highest differences for Byrsonima in preserved sites (Table 1). We found higher proportions of diaspores removed in control treatments for the three species, with significant difference for Davilla and Miconia in both site types, and for Byrsonima with significant difference only in preserved areas $\left(\chi^{2}=5.16, \mathrm{P}<0.1 ;\right.$ Fig. 1$)$. Despite the significant role of vertebrates in diaspore removal, most removal events were attributed to invertebrates in both plot types (Fig. 1). 
Experiment B. Diaspore observation experiment

Ants were the only group of animals recorded interacting with the diaspores during the direct diurnal observations. We observed that more than $66 \%$ of all diaspore-ant interactions occurred in preserved sites for each of the three plant species monitored (Table 2), with a significant difference between site types for all species (Fig. 2).

Byrsonima presented the highest number of depulping events (three in each site type), as well as the higher number of diaspores taken into ant nests (two in disturbed sites and one in preserved sites; Table 2). Considering all diaspores removal events for the three plant species in disturbed sites, $24 \%$ (i.e. $n=4$ ) resulted in the displacement of the diaspore from disturbed to preserved sites. Conversely, no ant species transported diaspores from preserved to disturbed sites (Table 2). The maximum dispersal distance (42 meters) was observed for Byrsonima, dispersed by Atta laevigata in a preserved site. We found significant differences between diaspore types $\left(\chi^{2}=19.78, \mathrm{p}=0.043\right)$, with high removal distances for Byrsonima, but no significant differences between site types for any of the species (Fig. 3).

\section{Experiment B. Ant-diaspore interactions}

We recorded 20 ant species performing 477 interaction events with the diaspores, of which 65\% were recorded in preserved sites (Appendix S3). From all records, $7 \%$ represented diaspore removal events and nearly $2 \%$ corresponded to diaspore depulping (Table 2). Crematogaster sp1, Pheidole oxyops, Pheidole triconstricta had the highest total number of removal events across all diaspore types and sites (Appendix S3). Three ant species were only registered in disturbed sites: Brachymyrmex cordemoyi, Dolichoderinae sp. and Ectatomma tuberculatum (Appendix S3). Pheidole triostricta was the ant species responsible for $46 \%$ of diaspore interactions in disturbed sites (Appendix S3). Seed predator ants, such as Pheidole spp. and Dorymyrmex spp., did not have reduced activities in disturbed sites, with Pheidole triostricta 
even presenting higher number of interactions with diaspores in disturbed sites (Appendix S3). Seven ant species were recorded exclusively in preserved sites: Brachymyrmex pictus, Camponotus rufipes, Camponotus sp1, Crematogaster sp1, Pheidole sp2, Pheidole sp3, and Pheidole sp4 (Appendix S3). Crematogaster sp1 and Pheidole triconstricta were the species with the highest number of interactions with diaspores in preserved sites, representing $22 \%$ and $21 \%$ of all interaction records, respectively (Appendix S3).

The DRE landscapes indicated that depending on the site type, different ant species are more effective with regard to the dispersal service provided to plants (Figure 4). In preserved sites, Pheidole oxyops, Camponotus sp1, Crematogaster sp1 and Pheidole triconstricta were highly effective dispersers. Conversely, in disturbed sites Atta laevigata, Pheidole oxyops and Pheidole triconstricta were highly effective dispersers. Pheidole oxyops and Atta laevigata were highly effective in removing diaspores, and presented high values for qualitative components in both site types. Crematogaster sp1 and Pheidole triconstricta were highly effective in interacting with diaspores in preserved sites, as demonstrated by high quantitative component values for DRE, while in disturbed sites Pheidole triconstricta, Atta laevigata and Pheidole oxyops presented higher quantitative component values for DRE. Ectatomma tuberculatum presented high values of qualitative component for DRE only in disturbed sites, while Camponotus sp1 reached high values of qualitative component in preserved sites. Atta laevigata achieved distinct DRE values when comparing site types, with an average three times higher in disturbed sites than on preserved sites, as a result of high quantitative component values for DRE on preserved sites. The remaining species that do not appear in the landscape analysis presented very low DRE values.

Ant-diaspore interaction networks, formed by three distinct types of interactions (depulping, removing or only interacting) (Fig. 5), were more complex in preserved sites, and 
presented significant higher values for diversity of interactions $(\mathrm{F}=7.91 ; \mathrm{P}<0.05)$ and robustness $(\mathrm{F}=6.56 ; \mathrm{P}<0.05)$ (i.e., a more stable structure under random and cumulative extinctions of ant species) when compared to networks from disturbed sites (Fig. 6).

\section{Discussion}

Our data reveals that interactions between ground-foraging animals and diaspores in campo rupestre may influence seed fate and contribute to the typical low natural vegetation recovery observed after soil disturbance (Le Stradic et al. 2018b). We found that the quantity and quality of secondary seed dispersal can greatly vary between plant species and environmental conditions, supporting the idea that ground-foraging animals can target specific diaspore species (Roselli 2014), responding in different ways to disturbances (Schowalter et al. 1999; Wikars \& Schimmel 2001). Our findings indicates that topsoil disturbances modulate secondary seed dispersal by ants, a common interaction in Neotropical savannas (Christianini and Oliveira, 2009, 2010), and other OCBILs, such as the fynbos in South Africa and the kwongan in Southwestern Australia (Milewski \& Bond 1982; Traveset \& Rodríguez-Pérez 2008). Therefore, our results suggest that topsoil removal reshape the interactions between ground-foraging ants and diaspores, which may result in different outcomes for seed fate and consequently influence the recovery capacity of disturbed old-grow grasslands.

Diaspore interactions with ground-foraging animals seems to be reshaped in disturbed soils in campo rupestre, intensifying seed limitation and promoting dispersal constraint by: 1) decreasing the proportion and outcome of mutualistic interactions (seed depulping and dispersal); 2) increasing the activity of seed predator ants; 3) reallocating seeds from disturbed to preserved sites; 4) decreasing overall seed dispersal distance. The low diversity and robustness of ant-diaspore networks in disturbed sites suggest its lower stability and more 
conservative animal-diaspore networks (Bastazini et al. 2019), indicating lower partner diversity (i.e., potential dispersers) and greater vulnerability to collapse in case of ant species loss (or in a wider scale, disperser loss) in disturbed sites. The remarkable differences in ant species composition between sites (35\% of the ant species were exclusively found in preserved sites), and the significant differences in diaspore removal effectiveness (DRE) for most ant species between disturbed and preserved sites, reinforces that disturbance can strongly influence secondary diaspore removal dynamics and their ecological outcomes (Schoereder et al. 2004, see also Fernandes et al. 2019). These striking differences in qualitative and quantitative aspects of ant diaspore interactions between sites signalize that "ant limitation" (fewer species, lower abundances) and "dispersal service limitation" can be crucial aspects to better understand plant community assembly and recovery in campo rupestre.

At least half of diaspores of Byrsonima, Davilla and Miconia were removed within 48 hours, indicating that animal-diaspore interactions comprise an important ecological filter driving post-dispersal seed fate for these species and probably for many other plant species in edaphic grasslands. The marked reduction in the removal rates for Davilla in disturbed sites indicates the higher vulnerability of the foraging fauna that interact with the seeds of this plant species to soil disturbance. Byrsonima presented the higher quantity of depulping events and diaspores-taken-to-ant-nest observed. Likewise, Byrsonima diaspores accounted with the higher dispersal distances registered, suggesting a strong role of ground-foraging animals on the diaspore fate for this species and probably congeneric alike species, placing these plant species as a good model for future studies exploring the role of seed-animal interaction outcomes on plant recruitment. The negligible removal rates for Coccoloba and Stryphnodendron do not mean that their diaspores cannot represent a potential resource for ground-foraging animals, but that in a period of 48 hours these diaspores are unlikely to be removed in campo rupestre. Variation in fruit handling by primary avian seed dispersers in 
campo rupestre can be mediate by subsequent interactions among discarded diaspores and ground-dwelling animals, potentially affecting final seed fates (Guerra et al. 2018). Therefore, we should be especially cautious when evaluating the negligible removal rates for Coccoloba cereifera, which has bird-dispersed berries (Ribeiro \& Fernandes 1999).

Our study confirms that ant activity as secondary seed dispersers in campo rupestre vegetation (Lima et al. 2013, Guerra et al. 2018), is strongly affected by topsoil removal in disturbed areas. Nevertheless, while our diaspore observation experiment was diurnal only, post-dispersal diaspore interactions with vertebrates in campo rupestre must not be neglected. In fact, it is sustained by the significant differences found between treatments (vertebrateexclosure $v s$. control) in both preserved and disturbed sites, with higher removal rates for all species in the control treatment, meaning that vertebrates do remove between 5 and $16 \%$ of diaspores depending on site type and plant species. Guerra et al. (2018) showed that vertebrates can be important as secondary seed dispersers and seed predators in campo rupestre. Therefore, these results call attention for the role played by vertebrates as secondary dispersers or seed predators in vegetation recovery and dynamics in campo rupestre.

The ant species interacting with diaspores encompass well-represented ant genera in campo rupestre, such as Pheidole, Camponotus, Crematogaster and Dorymyrmex (Costa et al. 2015). The differences in the DRE values among ant species suggest specificity in the provision of important ecological services during this critical stage of plant recruitment (e.g. depulping, direct dispersal). Species in Pheidole displayed the highest interaction frequency and the highest number of removals, culminating relevant values in DRE in both site types. Pheidole and Atta are mostly granivorous and the possible outcomes of these interactions in plant community assembly (e.g. seed limitation) for campo rupestre should be investigated to better understand its ecological function on seed fate (Christianini et al. 2009; Guerra et al. 2018). Species of Crematogaster, Pheidole and Camponotus presented the highest values for DRE in 
preserved sites, suggesting their crucial role in structuring the interaction network of diaspores and foraging animals in preserved areas of campo rupestre.

Pheidole spp. seems to be highly tolerant to soil removal disturbance in campo rupestre and may hamper natural recovery by seed predation (Denham 2008). Atta laevigata, Pheidole triconstricta and Pheidole oxyops were the species with high number of interactions and DRE values in disturbed sites. Also Atta laevigata seems to benefits from disturbance (Vieira-Neto et al. 2016), which is supported by a high DRE in disturbed sites, with an average of DRE values three times higher in disturbed than in preserved sites. However, workers of Atta laevigata may deplete soil seed banks in degraded sites by moving diaspores from degraded to preserved sites, thus limiting plant recruitment (Vaz Ferreira et al. 2011).

The predominance of short dispersal distances $(<5 \mathrm{~cm})$ in our experiments are in accordance with previous evidence that show ants as short-distance seed dispersers (Christianini \& Oliveira 2010; Gómez \& Spadaler 2013; Camargo et al. 2016, Guerra et al. 2018). The majority of species observed are small ant species, suggesting that disperser body size is a key trait determining the outcomes of ant-plant interactions (Warren and Giladi 2014; Magalhães et al. 2018). Small ants usually only consume fruit pulps on the spot and do not remove the diaspores far away from their initial location (Ness et al. 2004), which is confirmed by the predominance of high qualitative values of DRE attributed to the larger ant species observed. Our single observation of a long dispersal distance for Byrsonima (42 meters) was carried by Atta laevigata, the largest ant species observed, reinforcing that large ants are able to provide greater dispersal distances than smaller ones (Ness et al. 2004). Species of the largebody-sized Ectatomma dispersed seeds to relevant distances (approximately 10 meters). However, differently from Atta laevigata, Ectatomma species were responsible for most of the depulping events in preserved sites and were thus a most valuable disperser in preserved sites (Magalhães et al. 2018). Pulp removal is a relevant ecological service, as it decreases the 
chances of fungal attack (Ohkaware \& Akino 2005), and creates conditions for germination of light-demanding seeds, as the case of the Miconia (Lima et al. 2013).

\section{Conclusion}

Our results suggest that disturbance resulted in structurally different networks involving diaspores and ground-foraging animals, showing that secondary seed dispersal by ants potentially affect vegetation dynamics and resilience. Previous studies have found that variation in secondary diaspore-animal interactions is linked to habitat conservation status (Schupp \& Fuentes 1995; Chapman \& Chapman 1996; Lambert 2002), and here we show contrasting outcomes arising from animal-plant interactions between disturbed and preserved sites. Topsoil removal affected the robustness of diaspore-animal networks and modified the effectiveness of diaspore removal by ant species, which has potential implications for recruitment.

The lack of diaspore dispersal towards disturbed sites and diaspore disposal in preserved sites may strongly influence dispersal limitation and hamper natural recovery (Hopper et al. 2016), providing a mechanistic explanation for high vulnerability to soil removal in edaphic grasslands (sensu Buisson et al. 2019). Our results become even more relevant considering that campo rupestre is a seed-limited ecosystem (Dayrell et al. 2016; Le Stradic et al. 2018), where any reduction in seed quantity may heavily compromises plant recruitment and natural regeneration (Calviño-Cancela 2007; Silveira et al. 2016).

In sum, our findings contribute to the current knowledge on establishment filter in a megadiverse tropical grassland, as it provides evidence on how disturbance can reshape diaspore interactions with ground-foraging animals. The next steps should move forward to explore the ecological outcomes on seed fate between preserved and disturbed sites. This will inform how disturbance modulates the establishment filter and support effective conservation 
and restoration practices (Chambers \& MacMahon 1994; Turnbull et al. 2000; Bulot et al. 2014).

\section{Acknowledgments}

We thank L.D. Braga and C.S. Oliveira for assisting in the experiments and lab work. We also thank Parque Nacional da Serra do Cipó/ICMBio and Reserva Vellozia for the logistic support. T. Dutoit, G. Durigan, A. Fidelis, J. Sansevero and T. Cornelissen provided comments in early versions of the manuscript. A.J.A. and F.V.C. receives a scholarship from FAPEMIG and CAPES, and F.A.O.S. receives grants from CNPq and FAPEMIG. RLC Dayrell received scholarship from CAPES and a Scholarship for International Research Fees at UWA. This work was also supported by CNRS PICS 2018-2020 [RESIGRASS]. The authors declare no conflict of interest.

\section{Authors' contributions}

A.J.A, F.A.O.S., T.J.G., F.V.C. and E.B conceived the ideas and designed methodology; A.J.A., P.A.J., H.T.S.R., T.J.G., F.V.C., J.V.S.M.. R.L.C.D and E.B. collected the data; A.J.A., T.J.G., and F.V.C. analyzed the data; A.J.A. led the writing of the manuscript with inputs from T.J.G., F.V.C., F.A.O.S and E.B. All authors contributed critically to the drafts and gave final approval for publication.

\section{Supporting Information}

Appendix S1. Photos of the five native diaspores used, three native fruits: Miconia irwinii (Melastomataceae), Byrsonima vacciniifolia (Malpighiaceae) and Coccoloba cereifera 
(Polygonaceae); and two native seeds: Stryphnodendron gracile (Fabaceae) and Davilla

491

492

493

494

495

496

497

498

499

500

501

502

503

504

505

506

507

508

509

510

511

elliptica (Dilleniaceae) (Photos A.J. Arruda).

Appendix S2. Experiment sampling designs for the 48 hours removal trial and focal experiments.

Appendix S3. Ant species registered, their functional groups and number of interactions realized according to diaspore and site type for each ant species ( $\mathrm{PR}=$ preserved, $\mathrm{DI}=$ disturbed $)$.

\section{Data availability statement}

Primary datasets and statistical analysis scripts are available at DOI 10.5281/zenodo.3564943.

\section{References}

Arnan, X., Molowny-Horas, R., Rodrigo, A., Retana, J. (2012). Uncoupling the Effects of Seed Predation and Seed Dispersal by Granivorous Ants on Plant Population Dynamics. PLoS ONE, 7(8), e42869.

Almeida-Neto, M., Guimaraes, P., Guimaraes, P.R., Loyola, R.D. \& Ulrich, W. (2008). A consistent metric for nestedness analysis in ecological systems: reconciling concept and measurement. Oikos ,117, 1227-1239.

Baccaro, F.B., Feitosa, R.M., Fernández, F., Fernandes, I.O., Izzo, T.J., Souza, J.L.P., Solar, R.R.C. (2015). Guia para os gêneros de formigas do Brasil. INPA, (Manaus, Brazil).

Bakker, J.P., Poschlod, P., Strykstra, R.J., Bekker, R.M. \& Thompson, K. (1996). Seed banks and seed dispersal: important topics in restoration ecology. Acta Botanica Neerlandica, $45,461-490$. 
Bastazini, V., Debastiani, V., Azambuja, B., Guimarães, P., \& Pillar, V. (2019). Loss of Generalist Plant Species and Functional Diversity Decreases the Robustness of a Seed Dispersal Network. Environmental Conservation, 46(1), 52-58.

Bates, D., Machler, M., Bolker, B. \& Walker, S. (2014). Fitting linear mixed-effects models using lme4. Drug Information Journal, 35, 1215-1225.

Batagelj V. \& Mrvar, A. (1998). Pajeka program for large network analysis. Connections, 21, 47-57.

Bersier, L.F., Banasek-Richter, C. \& Cattin, M.F. (2002). Quantitative descriptors of food-web matrices. Ecology, 83, 2394-2407.

Blüthgen, N., Fründ, J., Vázquez, D.P. \& Menzel, F. (2008). What do interaction network metrics tell us about specialization and biological traits? Ecology, 89, 3387-3399.

Bulot, A., Thierry, D., Renucci, M. \& Provost, E. (2014). A new transplantation protocol for harvester ant queens Messor barbarus (Hymenoptera: Formicidae) to improve the restoration of species-rich plant communities. Myrmecological News, 20, 43-52.

Burgos, E., Ceva, H., Perazzo, R.P.J., Devoto, M., Medan, D., Zimmermann, M. \& Delbue, A.M. (2007). Why nestedness in mutualistic networks? Journal of Theoretical Biology, 249, 307-313.

Bolker, B.M. (2015). Linear and generalized linear mixed models. In G. A. Fox, S. NegreteYankelevich, \& V. J. Sosa (Eds.), Ecological statistics: Contemporary theory and application. Oxford University Press.

Bond, W.J. \& Parr, C.L. (2010). Beyond the forest edge: ecology, diversity and conservation of the grassy biomes. Biological Conservation, 143, 2395-2404.

Buisson, E., Dutoit, T., Torre, F., Römermann, C. \& Poschlod, P. (2006). The implications of seed rain and seed bank patterns for plant succession at the edges of abandoned fields in Mediterranean landscapes. Agriculture, Ecosystems \& Environment, 115, 6-14. 
Buisson, E., Le Stradic, S., Silveira, F.A.O., Durigan, G., Overbeck, G.E., Fidelis, A., Fernandes, G.W., Bond, W.J., Hermann, J., Mahy, G., Alvarado, S.T., Zaloumis, N.P. \& Veldman, J.W. (2019). Resilience and restoration of tropical and subtropical grasslands, savannas, and grassy woodlands. Biological Reviews, 94, 590-609.

Calviño-Cancela, M. (2007). Seed and microsite limitations of recruitment and the impacts of post-dispersal seed predation at the within population level. Plant Ecology ,192 (1), $35-44$.

Camargo, P.H.S.A., Rodrigues, S.B.M., Piratelli, A.J., Oliveira, P.S. Christianini, A.V. (2019). Interhabitat variation in diplochory: Seed dispersal effectiveness by birds and ants differs between tropical forest and savanna. Perspectives in Plant Ecology, Evolution and Systematics, 38, 48-57.

Campbell, D.R., Rochefort, L. \& Lavoie, C. (2003). Determining the immigration potential of plants colonizing disturbed environments: the case of milled peatlands in Quebec. Journal of Applied Ecology, 40, 78-91.

Chambers, J.C. \& MacMahon, J.A. (1994). A day in the life of a seed: movements and fates of seeds and their implications for natural and managed systems. Annual Review of Ecology, Evolution and Systematics, 25 (1), 263-292.

Chamberlain, S.A., Bronstein, J.L. \& Rudgers, J.A. (2014). How context dependent are species interactions? Etienne R, editor. Ecology Letters, 17, 881-890.

Chapman, C.A. \& Chapman, L.J. (1996). Frugivory and the fate of dispersed and non-dispersed seeds of six African tree species. Journal of Tropical Ecology, 12, 491-504.

Colli-Silva, M., Vasconcelos, T.N.C. \& Pirani, J.R. (2019). Outstanding plant endemism levels strongly support the recognition of campo rupestre provinces in mountaintops of eastern South America. Journal of Biogeography 00, 1- 11. 
Costa, F.V., Mello, R., Lana, T.C. \& Neves, F.S. (2015). Ant fauna in megadiverse mountains: a checklist for the rocky grasslands. Sociobiology, 62, 228-245.

Costa, F.V., Mello, M.A.R., Bronstein, J.L., Guerra, T.J., Muylaert, R.L., Leite, A.C. \& Neves, F.S. (2016). Few ant species play a central role linking different plant resources in a network in rupestrian grasslands. PLoS One 11, e0167161.

Costa, A.N., Vasconcelos, H.L. \& Bruna, E. M. (2017). Biotic drivers of seedling establishment in Neotropical savannas: selective granivory and seedling herbivory by leaf-cutter ants as an ecological filter. Journal of Ecology, 105, 132-141.

Costa, F.V., Blüthgen, N., Viana-junior, A., Guerra, T.J., Spirito, L. \& Neves, F.S. (2018). Resilience to fire and climate seasonality drive the temporal dynamics of ant-plant interactions in a fire-prone ecosystem. Ecological Indicators, 93, 247-255.

Conceição, A.A., Rapini, A., Carmo, F.F., Brito, J.C., Silva, G.A., Neves, S.P.S. \& Jacobi, C.M. (2016). Rupestrian Grassland vegetation, diversity, and origin. In: Fernandes GW (ed) Ecology and conservation of mountaintop grasslands in Brazil. Springer International Publishing, Switzerland, 105-127 pp.

Crawley, M.J. (2013). The R Book, Second Ed (ed Crawley MJ). Wiley, United Kingdom

Christianini, A.V., Mayhé-Nunes, A., \& Oliveira, P. (2007). The role of ants in the removal of non-myrmecochorous diaspores and seed germination in a neotropical savanna. Journal of Tropical Ecology, 23 (3), 343-351.

Christianini, A.V. \& Oliveira P.S. (2009). The relevance of ants as seed rescuers of a primarily bird-dispersal tree in the Neotropical cerrado savanna. Oecologia, 160, 735-745.

Christianini, A.V. \& Oliveira, P. S. (2010). Birds and ants provide complementary seed dispersal in a Neotropical savanna. Journal of Ecology, 98, 573-582. 
Dayrell, R.L.C., Arruda, A.J., Buisson, E. \& Silveira, F.A.O. (2016). Overcoming challenges on using native seeds for restoration of megadiverse resource-poor environments: a reply to Madsen et al. Restoration Ecology, 24, 710-713.

De Lima, M.P.M. (1985). Morfologia dos frutos e sementes dos gêneros da tripo Mimoseae (Leguminosae-Mimosoidae) aplicada a sistemática. Rodriguésia, 37 (62), 53-78.

Denham, A.J. (2008). Seed predation limits post-fire recruitment in the waratah (Telopea speciosissima). Plant Ecology, 199, 9-19.

Dennis, A.J. \& Westcott, D.A. (2007). Estimating dispersal kernels produced by a diverse community of vertebrates. In: Dennis A.J., Schupp, E.W., Green, R.J., Westcott, D.A., eds. Seed dispersal: theory and its application in a changing world. Wallingford, UK: CAB International, 201-228.

Dirzo, R. \& Domingez, C.A. (1986). Seed shadows, seed predation and the advantages of dispersal. In Estrada, A. \& Fleming, T.H. (Eds.). Frugivores and seed dispersal, pp. 237-249. Dr W. Junk Publishers, Dordrecht, The Netherlands.

Dormann, C.F., Gruber, B. \& Fründ, J. (2008). Introducing the bipartite package: analysing ecological networks. R News, 8, 8-11.

Echternacht, L., Trovó, M., Oliveira, C.T. \& Pirani, J.R. (2011). Areas of endemism in the Espinhaço Range in Minas Gerais, Brazil. Flora 206, 782-791.

Fagundes, R., Anjos, D.V., Carvalho, R. \& Del-Claro, K. (2015). Availability of food and nesting-sites as regulatory mechanisms for the recovery of ant diversity after fire disturbance. Sociobiology 62(1), 1-9.

Feer, F. \& Forget, P. (2002). Spatio-temporal variations in post-dispersal seed fate. Biotropica, $34,555-566$.

Fernandes, G.W., Barbosa, N.P.U., Alberton, B., Barbieri, A., Dirzo, R., Goulart, F., Guerra, T.J., Morellato, L.P.C. \& Solar, R.R.C. (2018). The deadly route to collapse and the 

$-2603$.

Fernandes, G.W. (2016). Ecology and conservation of mountaintop grasslands in Brazil. Springer International Publishing, Switzerland.

Fernandes, T.V., Paolucci, L.N., Solar, R.R.C. et al. Oecologia (2019). Ant removal distance, but not seed manipulation and deposition site increases the establishment of a myrmecochorous plant. Oecologia, 1-10.

Fraga, C.N. (2012). Filogenia e revisão taxonômica de Davilla Vand. (Dilleniaceae). PhD Thesis, Universidade Federal de Minas Gerais, Belo Horizonte, Brazil.

Genrich, C.M., Mello, M.A., Silveira, F.A.O., Bronstein, J.L. \& Paglia, A.P. (2017). Duality of interaction outcomes in a plant-frugivore multilayer network. Oikos, 126, 361-368.

Gómez, C. \& Espadaler, X. (2013). An update of the world survey of myrmecochorous dispersal distances. Ecography, 36, 1193-1201.

Gómez, J.M., Schupp, E.W. and Jordano, P. (2019). Synzoochory: the ecological and evolutionary relevance of a dual interaction. Biological Review, 94, 874-902.

Grubb, P. J. (1977). The maintenance of species richness in plant communities: the importance of the recovery niche. Biological Reviews, 52, 107-145.

Guerra, T.J., Carstensen, D.W., Morellato, L.P. C., Silveira, F.A.O., Costa, F.V. (2016). Mutualistic interactions among free-living species in Rupestrian Grasslands. Ecology and Conservation of Mountaintop Grasslands in Brazil (Fernandes, G.W.), Springer International Publishing, Swithzerland, 291-314 pp.

Guerra, T.J., Dayrell, R.L.C., Arruda, A.J. et al. (2017). Intraspecific variation in fruit-frugivore interactions: effects of fruiting neighborhood and consequences for seed dispersal. Oecologia, 185, 233-343. 
Guerra T.J., Messeder, J.V.S., Arruda, A.J., Fuzessy, L.F., Dayrell, R.L.C., Neves, F.S. et al. (2018). Handling by avian frugivores affects diaspore secondary removal. PLoS ONE 13(8): e0202435.

Guerra, T.J., Pizo, M.A. (2014). Asymmetrical dependence between a Neotropical mistletoe and its avian seed disperser. Biotropica, 46, 285-293.

Hammond, S., \& Brown, V.K. (1998). Disturbance, phenology and life-history characteristics: factors influencing distanddensity-dependent attack on tropical seeds and seedlings. In Newbery, D.M. Prins, H.H.T. \& Brown, N. (Eds.). Dynamics of tropical communities. Blackwell Science, Oxford, England, 5, 1-78 pp.

Herrera, J.M., García, D. \& Morales, J.M. (2011). Matrix effects on plant-frugivore and plantpredator interactions in forest fragments. Landscape Ecology, 26, 125-135.

Hopper, S.D. (2009). OCBIL theory: towards an integrated understanding of the evolution, ecology and conservation of biodiversity on old, climatically buffered, infertile landscapes. Plant and Soil, 322, 49-86.

Janzen, DH. (1970). Herbivores and the number of tree species in tropical forests. The American Naturalist, 104, 501-528.

Lambert, J.E. (2002). Exploring the link between animal frugivory and plant strategies: the case of primate fruit-processing and post-dispersal seed fate. In: Levey, D.J., Silva, W.R., Galetti, M. (eds) Seed dispersal and frugivory: ecology, evolution and conservation. CAB International, Wallingford, 365-379 pp.

Le Stradic, S., Buisson, E., Fernandes, G.W. (2015). Baseline data for the conservation of Neotropical mountain grasslands: vegetation composition and structure. Journal of Mountain Science 12: 864-877.

Le Stradic, S., Hernandez, P., Fernandes, G.W. \& Buisson, E. (2018a). Recovery after fire in campo rupestre: short- and long-term vegetation dynamics. Flora, 238, 191-200. 
Le Stradic, S., Fernandes, G.W. \& Buisson, E. (2018b). No recovery of campo rupestre grasslands after gravel extraction: implications for conservation and restoration. Restoration Ecology, 26, S151-S159.

Leal, I.R., Wirth, R. \& Tabarelli, M. (2007). Seed dispersal by ants in the semi-arid Caatinga of North-East Brazil. Annals of Botany, 99, 885-894.

Lima, M.H., Oliveira, E.G. \& Silveira, F.A.O. (2013). Interactions between ants and nonmyrmecochorous fruits in Miconia (Melastomataceae) in a Neotropical Savanna. Biotropica 45, 217-223.

Mamede, M.C.H. \& Francener, A. (2015). Byrsonima in Lista de Espécies da Flora do Brasil. Jardim Botânico do Rio de Janeiro. Available in: <http://floradobrasil.jbrj.gov.br/jabot/floradobrasil/FB30459>. Accessed in 01 may 2019.

Magalhães, V.B., Espírito Santo, N.B., Salles, L.F.P., Soares, H. \& Oliveira, P.S. (2018). Secondary seed dispersal by ants in Neotropical cerrado savanna: species-specific effects on seeds and seedlings of Siparuna guianensis (Siparunaceae): Secondary seed dispersal by ants. Ecological Entomology, 43, 665-674.

Martinson, H.M. \& Fagan, W.F. (2014). Trophic disruption: A meta-analysis of how habitat fragmentation affects resource consumption in terrestrial arthropod systems. Ecology Letters, 17, 1178-1189.

Memmott, J., Waser, N.M. \& Price, M.V. (2004). Tolerance of pollination networks to species extinctions. Proceedings of the Royal Society of Botany, 271, 2605-2611.

Milewski, A.V. \& Bond, W.J. (1982). Convergence of myrmecochory in Mediterranean Australia and South Africa. In: Buckley RC (ed) Ant-plant interactions in Australia. Junk Press, The Hague, 89-98 pp. 
682

683

684

685

686

687

688

689

690

691

692

693

694

695

696

697

698

699

700

701

702

703

704

705

Mucina, L. (2018). Vegetation of Brazilian campos rupestres on siliceous substrates and their global analogues. Flora, 238, 11-23.

Ness, J.H., Bronstein, J.L., Andersen, A.N. \& Holland, J.N. (2004). Ant body size predicts dispersal distance of ant-adapted seeds: implications of small-ant invasions. Ecology, 85, 1244-1250.

Neves, F.S., Lana, T.C., Anjos, M.C., Reis, A.H. \& Fernandes, G.W. (2016). Ant community in burned and unburned sites in campos rupestres ecosystem. Sociobiology, 63(1), 628-636.

Occhioni, E.L.M. (1990). Considerações taxonômicas no gênero Stryphnodendron mart. (Leguminosae-mimosoideae) e dislribuiçáo geográflca das espécies. Acta Botanica Brasilica, 4(2), 153-158.

Ohkawara, K. \& Akino, T. (2005). Seed cleaning behavior by tropical ants and its anti-fungal effect. Journal of Ethology, 23 (2), 1439-5444.

Oliveira, P.S., Galetti, M., Pedroni, F. \& Morellato, L.P.C. (1995). Seed cleaning by Mycocepurus goeldii ants (Attini) facilitates germination in Hymenaea courbaril (Caesalpiniaceae). Biotropica, 27, 518-522.

Pan, Y., Bai, B., Xiong, T., Shi, P. \& Lu, C. (2016). Seed handling by primary frugivores differentially influence post-dispersal seed removal of Chinese yew by grounddwelling animals. Integrative Zoology, 11, 191-198.

Parr, C.L., Lehmann, C.E.R., Bond, W.J., Hoffmann, W.A. \& Andersen, A.N. (2014). Tropical grassy biomes: misunderstood, neglected, and under threat. Trends in Ecology \& Evolution 29, 205-213.

Passos, L. \& Oliveira, P. (2003). Interactions between ants, fruits and seeds in a restinga forest in south-eastern Brazil. Journal of Tropical Ecology, 19 (3), 261-270. 
Pol, R.G., Lopez de Casenave, J. \& Pirk, G. I. (2011). Influence of temporal fluctuations in seed abundance on the foraging behaviour of harvester ants (Pogonomyrmex spp.) in the central Monte desert, Argentina. Austral Ecolog, 36, 320-328.

Pott, A. \& Pott, V.J. (1994). Plantas do Pantanal. Brasília: Embrapa, 320 pp.

R Core Team. (2017). R: A Language and Environment for Statistical Computing. https://www.R-project.org/

Retana, J., Pico, F. X. \& Rodrigo, A. (2004). Dual role of harvesting ants as seed predators and dispersers of a non-myrmecochorous Mediterranean perennial herb. Oikos, 105, 377385.

Rico-Gray, V. \& Oliveira P.S. (2007). The ecology and evolution of ant-plant interactions. The University of Chicago Press, Chicago, 320 pp.

Roberts, J. T. \& E. R. Heithaus. (1986). Ants rearrange the vertebrate-generated seed shadow of a neotropical fig tree. Ecology, 67, 1046-1051.

Roselli, S. (2014). The role of seed dispersal, seed predation and drought in the restoration of Ngel Nyaki Forest, Nigeria. Master's thesis, University of Canterbury, Christchurch, New Zealand.

Schoereder, J.H., Sobrinho, T.G., Ribas, C.R. \& Campos, R.B. (2004). Colonization and extinction of ant communities in a fragmented landscape. Austral Ecology, 29, 391398.

Schowalter, T. D. (2016). Insect ecology: An ecosystem approach (4rd ed). Academic Press. $774 \mathrm{pp}$.

Schupp, E. W. (1988). Factors affecting post-dispersal seed survival in a tropical forest. Oecologia, 76, 525-530.

Schupp, E.W. \& Fuentes, M. (1995). Spatial patterns of seed dispersal and the unification of plant population ecology. Ecoscience 2, 267-275. 
Schupp E.W., Jordano, P. \& Gómez, J.M. (2010). Seed dispersal effectiveness revisited: A conceptual review. New Phytologist 188, 333-353.

Schupp, E.W., Jordano, P. \& Gómez, J.M. (2017). A general framework for effectiveness concepts in mutualisms. Ecology Letters, 20, 577-590.

Shu, W.S., Ye, Z.H., Zhang, Z.Q., Lan, C.Y. \& Wong, M.H. (2005). Natural colonization of plants on five lead/zinc mine tailings in southern China. Restoration Ecology, 13, 4960.

Silveira, F.A.O., Negreiros, D., Barbosa, N.P.U., Buisson, E., Carmo, F.F., Carstensen, D.W., Conceição, A.A., Cornelissen, T.G., Echternacht, L., Fernandes, G.W., Garcia, Q.S., Guerra, T.J., Jacobi, C.M., Lemos-Filho, J.P., Le Stradic, S., Morellato, L.P.C., Neves, F.S., Oliveira, R.S., Schaefer, C.E., Viana, P.L. \& Lambers, H. (2016). Ecology and evolution of plant diversity in the endangered campo rupestre: a neglected conservation priority. Plant and Soil, 403, 129-152.

Sternberg, L.D., Pinzon, M. C., Moreira, M. Z., Moutinho, P., Rojas, E. I. \& Herre A. E. (2007). Plants use macronutrients accumulated in leaf-cutting ant nests. Proceedings of the Royal Society of London, 274, 315-321.

Tilman, D. 1997. Community invasibility, recruitment limitation, and grassland biodiversity. Ecology, 78, 81-92.

Thorsen, M.J., Seddon, P.J., Dickinson, K.J.M. (2011). Faunal influences on New Zealand seed dispersal characteristics. Evolutionary Ecology, 25, 1397-1426.

Török, P., Helm, A., Kiehl, K., Buisson, E. \& Valkó, O. (2018). Beyond the species pool: modification of species dispersal, establishment, and assembly by habitat restoration. Restoration Ecology, 26, S65-S72.

Traniello, J. (2010). Pheidole: Sociobiology of a Highly Diverse Genus, Editor(s): Michael D. Breed, Janice Moore. Encyclopedia of Animal Behavior, Academic Press, 699-706 pp. 
Traveset, A. \& Rodríguez-Pérez, J. (2008). The ecology of seed dispersal. Encyclopedia of Ecology (on line) Ed. S.E. Jorgensen. Elsevier.

Turnbull, L.A., Crawley, M.J. \& Rees, M. (2000). Are plant populations seed limited? A review of seed sowing experiments. Oikos, 88, 225-238.

Vander Wall, S.B. \& Longland, W.S., (2004). Diplochory: are two seed dispersers better than one? Trends in Ecology \& Evolution, 19, 155-161.

Vander Wall, S.B., K.M., Kuhn \& Beck, M.J. (2005). Seed removal, seed predation, and secondary dispersal. Ecology, 86, 801-806.

Vasconcelos, H.L., Vieira-Neto, E.H., Mundim, F.M. and Bruna, E.M. (2006). Roads Alter the Colonization Dynamics of a Keystone Herbivore in Neotropical Savannas. Biotropica, $38,661-665$.

Vaz Ferreira, A., Bruna, E.M. \& Vasconcelos, H. L. (2011). Seed predators limit plant recruitment in Neotropical savannas. Oikos, 120, 1013-1022.

Veldman, J.W., Buisson, E., Durigan, G., Fernandes, G.W., Le Stradic, S., Mahy, G., Negreiros, D., Overbeck, G.E., Veldman, R.G., Zaloumis, N.P., Putz, F.E. \& Bond, W.J. (2015). Toward an old-growth concept for grasslands, savannas, and woodlands. Frontiers in Ecology and the Environment, 13, 154-162.

Vieira-Neto, E.H., Vasconcelos, H.L. \& Bruna, E.M. (2016). Roads increase population growth rates of a native leaf-cutter ant in Neotropical savannahs. Journal if Applied Ecology, 53, 983-992.

Zuur, A.F., Leno, E.N., Walker, N.J., Saveliev, A.A. \& Smith, G.M. (2009). Mixed effects models and extensions in ecology with R. New York: Springer. 
Table 1: Percentage of diaspore removal for five plant species from campo rupestre grassland in treatments (vertebrate-exclosure (removal by invertebrates) and control (removal by vertebrates and invertebrates)) in preserved and disturbed sites, at Serra do Cipó, southeastern Brazil. Lowercase letters directly above percentage values indicate significant interactions between treatments and sites. When significant, Chi square $\left(\chi^{2}\right)$ and $\mathrm{P}$ values are presented for the generalized linear mixed model (GLMM) comparing fixed effects and interaction effects. "Site*Treat" represents significant interactions between site and treatments; "Site" represents significant differences between sites; "Treat" represents significant differences between treatments; N.S represents non-significant values for all fixed and interaction effects. See Figure 1 for differences between site types and cage treatments for species in bold.

\begin{tabular}{|c|c|c|c|c|}
\hline Species & Treatment & Preserved & Disturbed & GLMM \\
\hline \multirow{2}{*}{ Byrsonima vacciniifolia } & Exclosure & $27 \%^{a}$ & $27 \%^{\mathrm{a}}$ & \multirow{2}{*}{$\begin{array}{c}\text { Site } * \text { Treat: } \chi^{2}=5.16 \\
p=0.023\end{array}$} \\
\hline & Control & $43 \%{ }^{b}$ & $32 \%^{\mathrm{a}}$ & \\
\hline \multirow{2}{*}{ Davilla elliptica } & Exclosure & $78 \%$ & $48 \%$ & \multirow{2}{*}{$\begin{array}{c}\text { Site: } \chi^{2}=31.18, \\
\mathrm{p}<0.001 \text {; Treat: } \\
\mathrm{X}^{2}=8.11, \mathrm{p}=0.004\end{array}$} \\
\hline & Control & $83 \%$ & $58 \%$ & \\
\hline \multirow{2}{*}{ Coccoloba cereifera } & Exclosure & $<0.1 \%$ & $<0.1 \%$ & \multirow{2}{*}{ N.S. } \\
\hline & Control & $<0.1 \%$ & $<0.1 \%$ & \\
\hline \multirow{2}{*}{ Miconia irwinii } & Exclosure & $51 \%$ & $47 \%$ & \multirow{2}{*}{$\begin{array}{c}\text { Treat: } \chi^{2}=17.49, \\
p<0.001\end{array}$} \\
\hline & Control & $57 \%$ & $57 \%$ & \\
\hline \multirow{2}{*}{ Stryphnodendron gracile } & Exclosure & $<0.1 \%$ & $<0.1 \%$ & \multirow{2}{*}{ N.S. } \\
\hline & Control & $<0.1 \%$ & $<0.1 \%$ & \\
\hline
\end{tabular}


803

\begin{tabular}{lcccccc}
\hline Species & Site & Interaction & Removal & Depulping & Site change & Ants nest \\
\hline $\begin{array}{l}\text { Byrsonima } \\
\text { vacciniifolia }\end{array}$ & Disturbed & 37 & 3 & 3 & 2 & 2 \\
& Preserved & 110 & 3 & 2 & 0 & 1 \\
Davilla & Disturbed & 68 & 6 & 0 & 1 & 1 \\
elliptica & Preserved & 108 & 13 & 1 & 0 & 1 \\
Miconia & Disturbed & 60 & 8 & 0 & 1 & 0 \\
irwinii & Preserved & 142 & 4 & 1 & 0 & 0
\end{tabular}

Table 2: Number of ant-diaspore interaction types observed for three plant species from disturbed and preserved campo rupestre sites, southeastern Brazil. Interaction types were classified as: Interaction $=$ total number of animal diaspore associations without pulp or diaspore removal; Removal: total number of diaspores removed over more than $5 \mathrm{~cm}$; Depulping: total number of events were ants removed diaspores pulp; Site change $=$ total number of observations when the final diaspore destination was different from the site of origin; Ants nest $=$ total number of diaspores taken into an ant nest. 


\section{A. Byrsonima vacciniifoila}

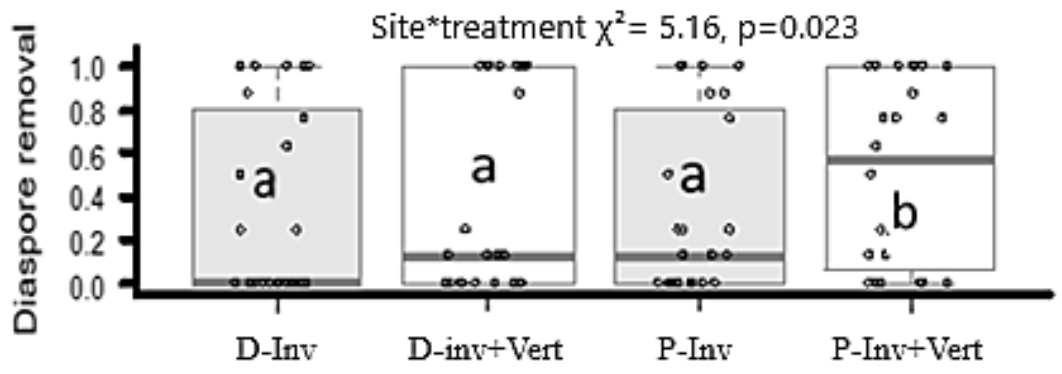

\section{B. Davilla elliptica}
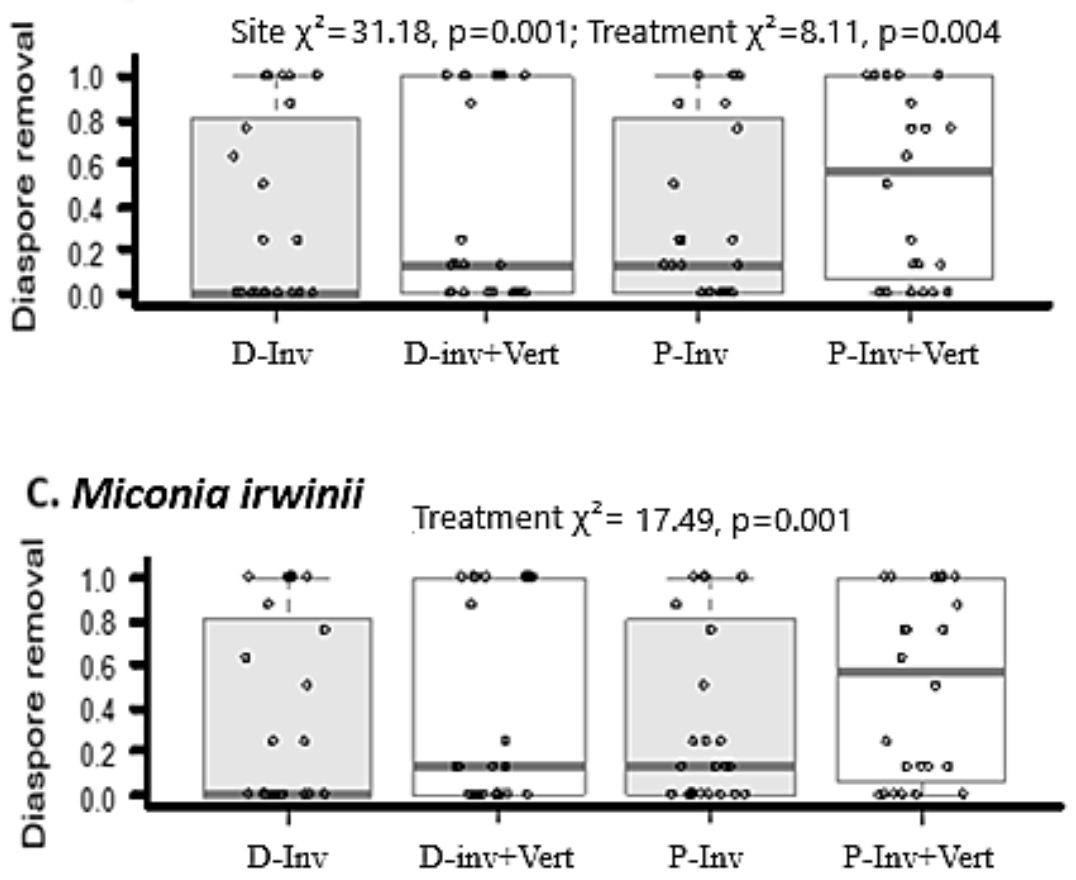

Figure 1. Diaspore removal rates in each treatment along disturbed and preserved sites of campo rupestre vegetation, southeastern Brazil. Different lowercase letters inside boxplots indicate significant statistical differences for Byrsonima vacciniifoila, which was the only diaspore to present significant interactions between treatments and sites (Site*treatment $\chi^{2}=$ 5.16, $\mathrm{p}=0.023$ ). As no significant interactions between treatments and sites were found for Davilla elliptica and Miconia irwinii, only significant statistical values for differences within treatments and/ or sites are represented above the boxplots: Davilla elliptica (Site $\chi^{2}=31.18, \mathrm{p}$ $=0.001$; Treatment $\chi^{2}=8.11, \mathrm{p}=0.004$ ) and Miconia irwinii (Treatment $\chi^{2}=17.49, \mathrm{p}=0.001$ ). Inv only $=$ access to invertebrates only $=$ vertebrate exclusion (or wired cage treatment); Vert + Inv $=$ access to both vertebrates and invertebrates (wired frame control treatment). $\mathrm{D}=$ disturbed sites; $\mathrm{P}=$ preserved sites 


\section{A. Byrsonima vacciniifolia}

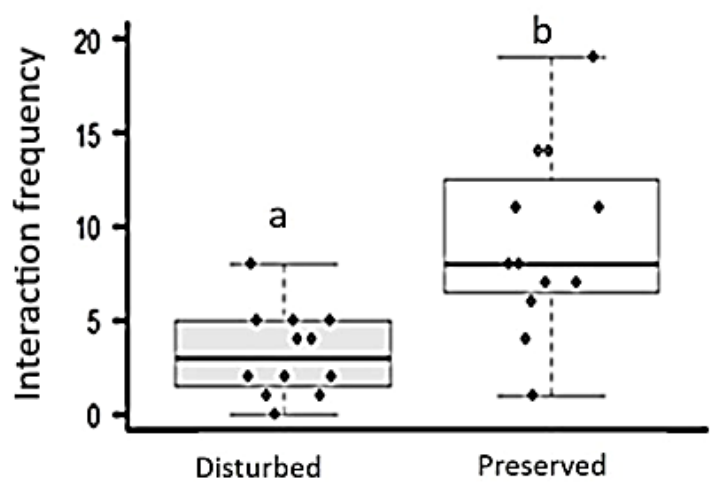

\section{B. Davilla elliptica}

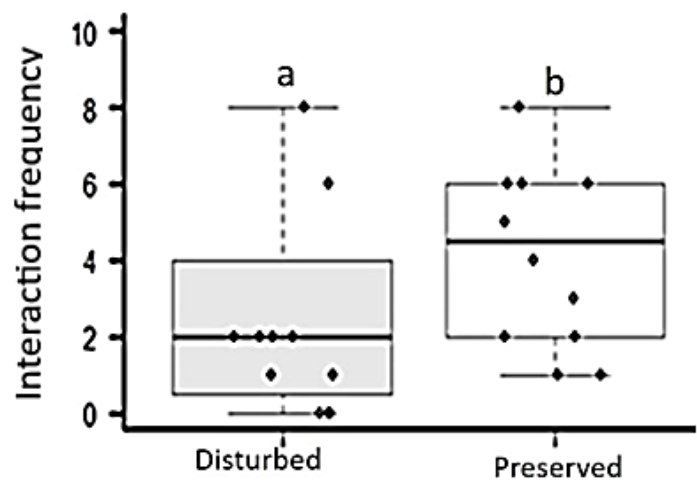

\section{Miconia irwinii}

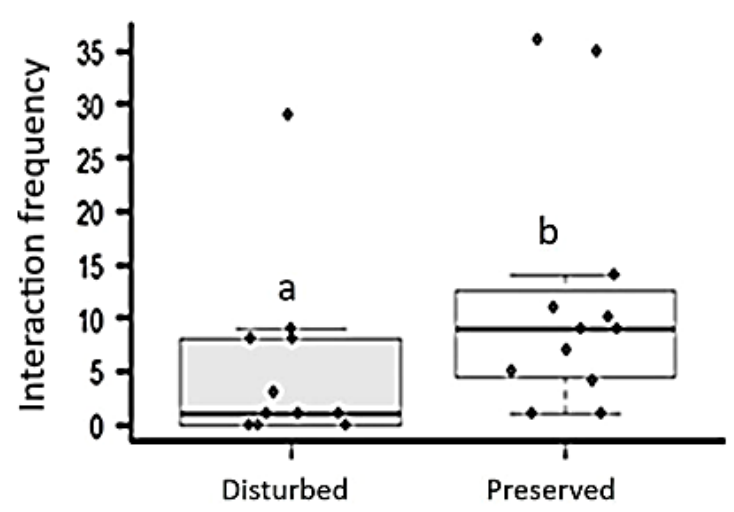

819 Figure 2: Interactions frequency at network level according to site type for three plant species

820 from of campo rupestre vegetation, southeastern Brazil. Different letters indicate significant 821 differences between site types for Byrsonima vacciniifoila $\left(\chi^{2}=19.78, \mathrm{p}<0.001\right)$; Davilla 822 elliptica $\left(\chi^{2}=9.17, \mathrm{p}<0.001\right)$ and Miconia irwinii $\left(\chi^{2}=19.78, \mathrm{p}<0.01\right)$. The boxplots represent the 823 median (middle line), $25 \%$ and $75 \%$ percentiles (the lower and upper boundaries of the boxes, 824 respectively), and the 1.5 interquartile range (whiskers). Black circles indicate individual data 825 points. 


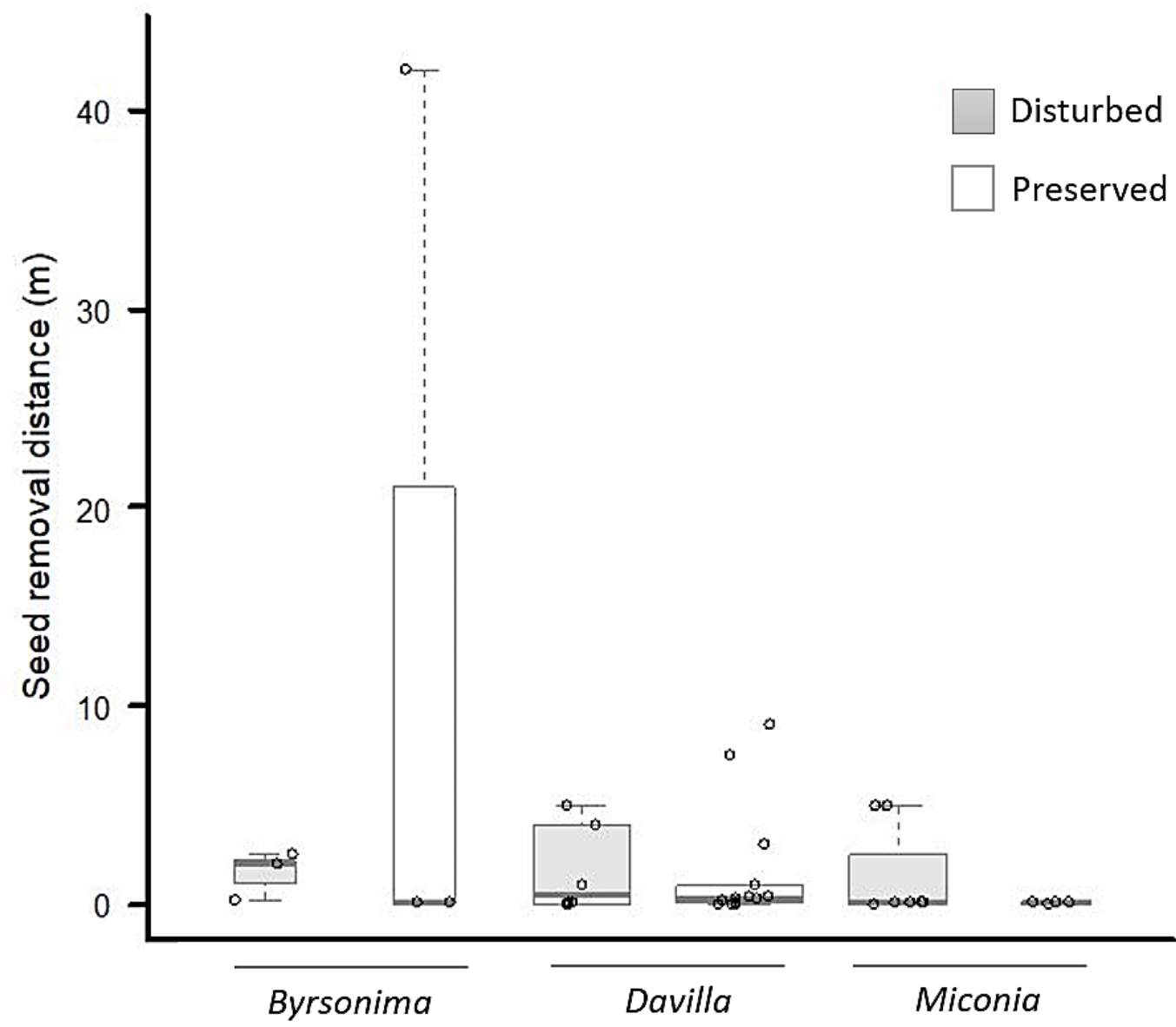

827

828 Figure 3: Mean dispersal distances (meters) for diaspores of Byrsonima vacciniifolia, Davilla 829 elliptica and Miconia irwinii in disturbed and preserved campo rupestre sites, southeastern 830 Brazil. The boxplots represent the median (middle line), $25 \%$ and $75 \%$ percentiles (the lower 831 and upper boundaries of the boxes, respectively), and the 1.5 interquartile range (whiskers). 832 Circles indicate individual data points. Significant differences between diaspores represented 833 by $\chi^{2}=19.78, \mathrm{p}=0.043$. 


\section{Disturbed}

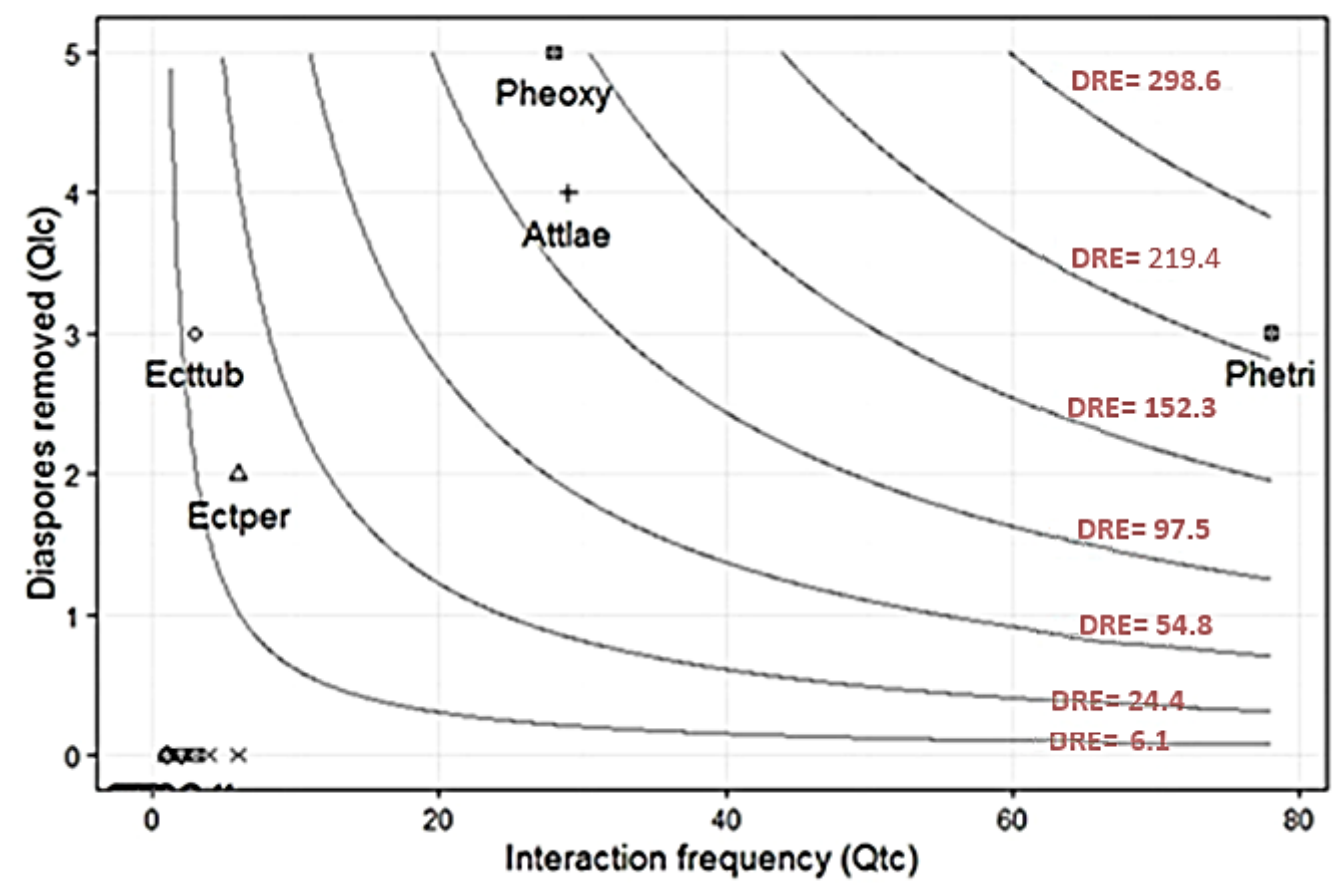

Preserved

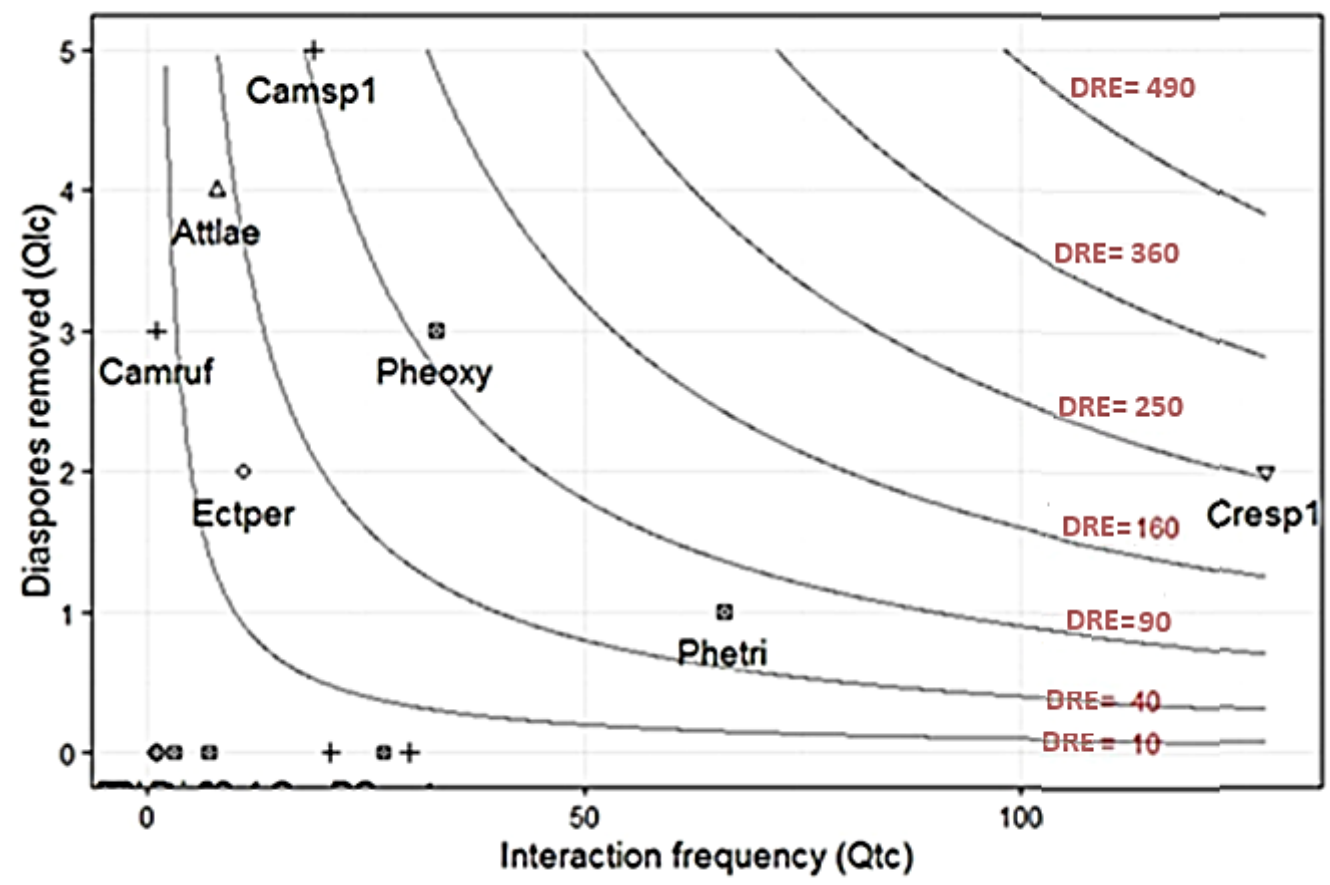

Figure 4: Diaspore removal effectiveness landscape (DRE $=$ Quantity $\times$ Quality) of all ant species interacting with diaspores of Byrsonima vacciniifolia, Davilla elliptica and Miconia irwinii in preserved and disturbed campo rupestre sites in southeastern Brazil. Isoclines represent all combinations of quantity and quality components with the same value of DRE adapted from Schupp et al. (2017). Symbols represent distinct functional groups of ant species. Ants' codes and symbols definition can be found in Appendix S3. 

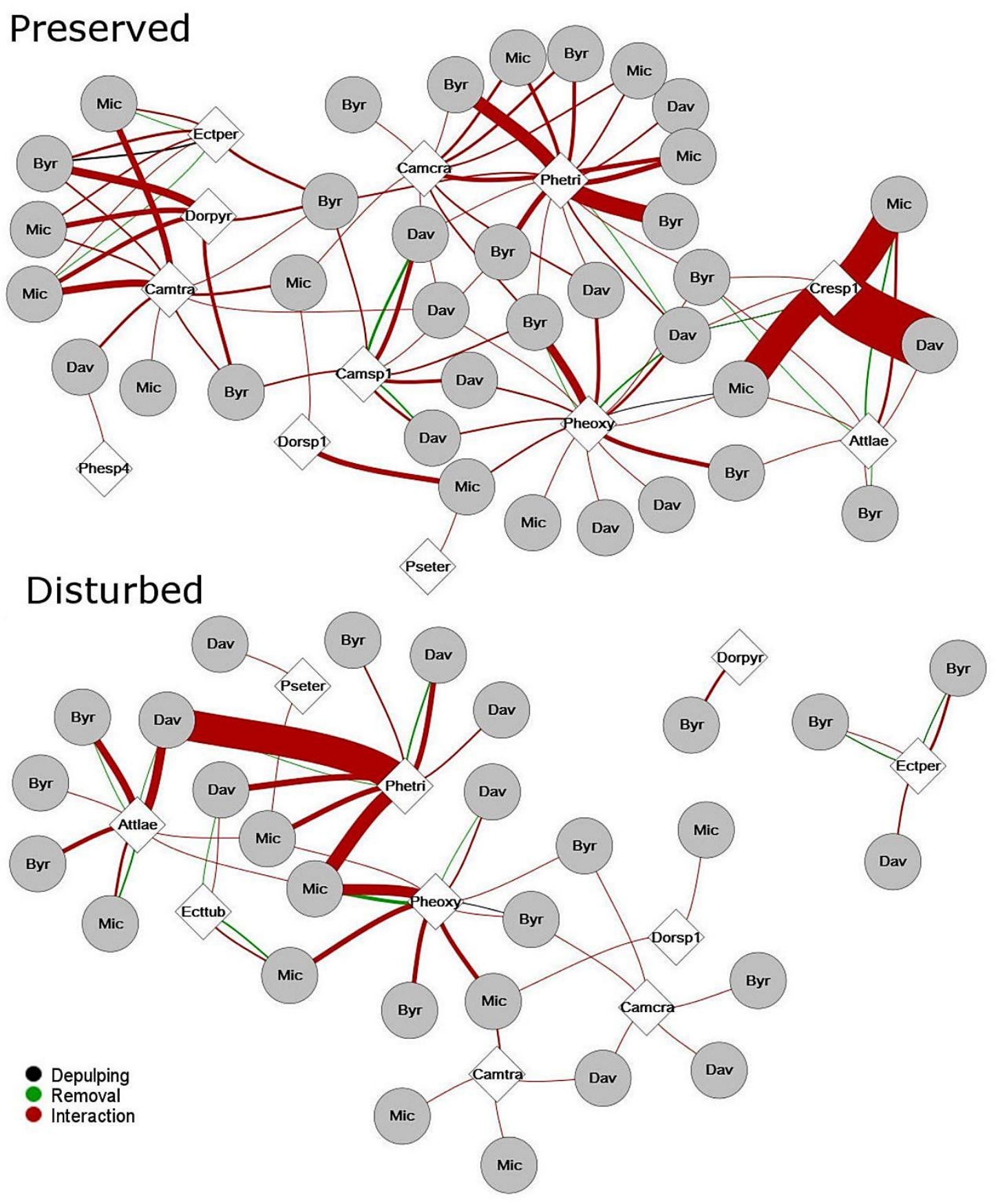

845 Figure 5: Ant-diaspore multilayer networks in preserved and disturbed campo rupestre sites, considering distinct types of interactions according to ant behavior (represented by distinct colors). Line width represents the frequency of interactions. Diamonds depict ant species, with ant codes provided in Appendix S3. Circles represent distinct stations inside each site. (Interaction $=$ diaspore manipulation without pulp removal or removal further than $5 \mathrm{~cm}$, Depulping = diaspore pulp removal; Removal $=$ diaspore displacement further than $5 \mathrm{~cm}$; Byr = Byrsonima vacciniifolia $;$ Dav = Davilla elliptica ; Mic = Miconia irwinii). 


\section{A) Shannon diversity}

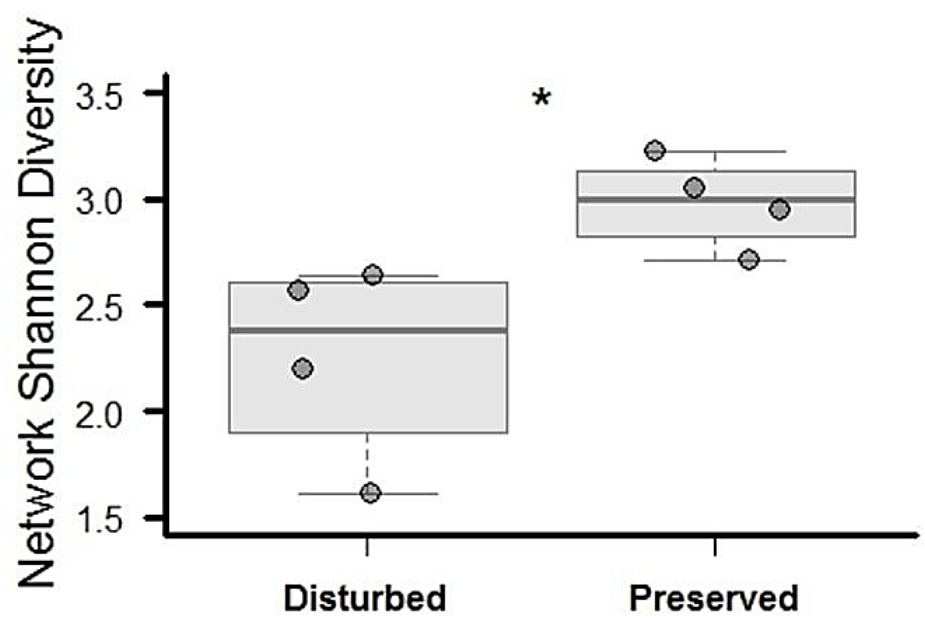

B) Network robustness

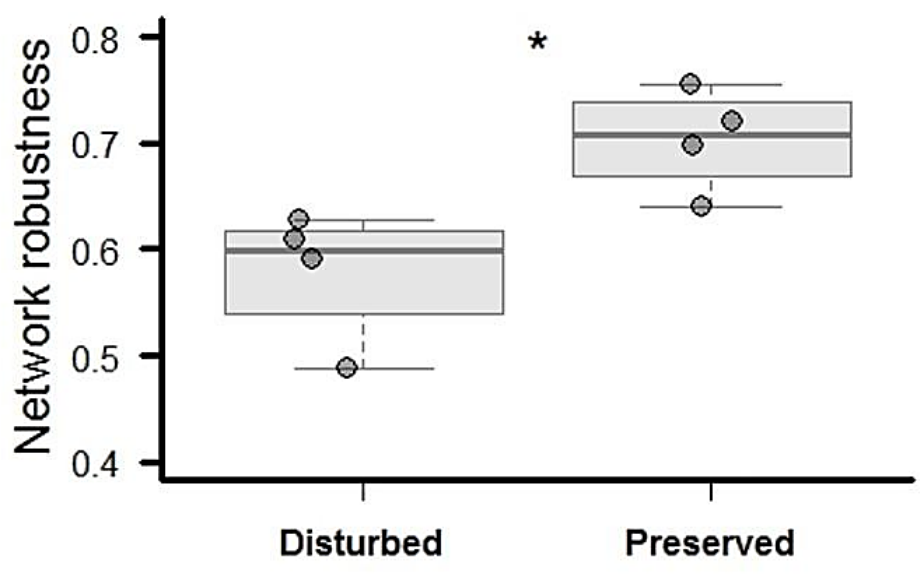

854 Figure 6: A) Interactions' Shannon diversity index and B) networks robustness under ant 855 species cumulative random extinctions for ant-diaspores networks in preserved and disturbed 856 campo rupestre sites, southeastern Brazil. * represents significant differences between site 857 types for Shannon diversity of interactions $(\mathrm{F}=7.91 ; \mathrm{P}<0.05)$ and networks robustness $(\mathrm{F}=$ $858 \quad 6.56 ; \mathrm{P}<0.05$ ). The boxplots represent the median (middle line), $25 \%$ and $75 \%$ percentiles (the 859 lower and upper boundaries of the boxes, respectively), and the 1.5 interquartile range 860 (whiskers). Dark gray circles indicate individual data points. 